\title{
Quality of in-shell Brazil nuts after drying using a pilot natural convection oven in the state of Acre, Brazil
}

\author{
Qualidade da castanha-do-brasil com casca após secagem usando um forno-piloto \\ por convecção natural, no estado do Acre, Brasil
}

\section{David Aquino da Costa', Virgínia de Souza Álvares ${ }^{2 *}$, Jorge Ferreira Kusdra1, Roberta Martins Nogueira ${ }^{3}$, Vlayrton Tomé Maciel'2, Daniela Popim Miqueloni'}

\author{
1 Universidade Federal do Acre (UFAC), Centro de Ciências Biológicas e da Natureza, Rio Branco/AC - Brazil \\ 2 Empresa Brasileira de Pesquisa Agropecuária (Embrapa), Laboratório de Tecnologia de Alimentos, Rio Branco/AC - Brazil \\ ${ }^{3}$ Universidade Federal de Mato Grosso (UFMT), Instituto de Ciências Agrícolas e Ambientais, Sinop/MT - Brazil
}

\section{*Corresponding Author:}

Virgínia de Souza Álvares, Empresa Brasileira de Pesquisa Agropecuária (Embrapa), Laboratório de Tecnologia de Alimentos, BR 364, km 14, CEP. 69900-970, Rio Branco/AC - Brazil, e-mail: virginia.alvares@embrapa.br

Cite as: Quality of in-shell Brazil nuts after drying using a pilot natural convection oven in the state of Acre, Brazil. Braz. J. Food Technol., v. 20, e2015104, 2017

Received: Dec. 15, 2015; Accepted: May 31, 2017

\section{Abstract}

The natural drying of in-shell Brazil nuts carried out by the extractivists is not effective in reducing contamination by aflatoxin-producing fungi. Thus the use of an artificial heater could prove to be a favourable method to bring about a rapid reduction in the moisture content of the nuts and thereby prevent fungal growth. Hence the objective of this study was to evaluate the efficiency of a natural convection-type drier with respect to the physical, physicochemical and microbiological quality of nuts after drying for 6 hours at $45^{\circ} \mathrm{C}$. A random block experimental design with two treatments (nuts before and after drying) was used, using 10 replications of $3 \mathrm{~kg}$. The nuts were analysed for their moisture, ash, protein, dietary fibre, total carbohydrates and lipid contents, water activity, total count of filamentous, potentially aflatoxin-producing fungi, and also the quantification of aflatoxins B1, B2, G1, G2 and the total aflatoxins. There was no effect of drying on the Aspergillus flavus and Aspergillus parasiticus counts or on the physicochemical composition of the nuts, except for the ash content. However the moisture content of the nuts was reduced by $39.7 \%$ and there was a decrease in the contamination by pre-existing total filamentous fungi. The dryer was effective in reducing the average time taken for drying as compared to the traditional method used by extractivists.

Keywords: Bertholletia excelsa; Aspergillus flavus; Aspergillus parasiticus; Aflatoxins.

\section{Resumo}

A secagem natural da castanha-do-brasil com casca, realizada por extrativistas, não é eficaz na redução da contaminação por fungos produtores de aflatoxinas. Portanto, o uso de um secador artificial pode ser um método para reduzir rapidamente o teor de umidade das amêndoas e, assim, prevenir o crescimento de fungos. Neste contexto, o presente estudo foi realizado para avaliar a eficiência de um secador, por convecção natural de ar, na qualidade física, físico-química e microbiológica das amêndoas após 6 horas de secagem, a $45^{\circ} \mathrm{C}$. O delineamento experimental foi em blocos casualizados, com dois tratamentos (castanhas antes e depois da secagem) e 10 repetições de $3 \mathrm{~kg}$. As amêndoas foram analisadas quanto a umidade, cinzas, proteína, fibra alimentar, carboidratos totais e lipídios, atividade de água, contagem total de fungos filamentosos e potencialmente produtores de aflatoxina, e quantificação de aflatoxinas $B_{1}, B_{2}, G_{1}, G_{2}$ e total. Não houve efeito da secagem na contagem de Aspergillus flavus e Aspergillus parasiticus, e também na composição físico-química das castanhas, exceto para teor de cinzas. No entanto, a umidade da amêndoa reduziu-se em 39,7\% e houve redução da contaminação pré-existente de fungos filamentosos totais. O secador é eficaz na redução do tempo médio de secagem quando comparado com o método tradicional usado pelos extrativistas.

Palavras-chave: Bertholletia excelsa; Aspergillus flavus; Aspergillus parasiticus; Aflatoxinas. 


\section{Introduction}

The Brazil nut tree (Bertholletia excelsa H.B.K.) is large-sized and can grow up to $60 \mathrm{~m}$ in height. It is found growing naturally in hot and humid climates, and has social, economic and environmental importance in the Amazon region.

Although the Brazil nut is found in several countries, in 2009 , Brazil accounted for $64.1 \%$ of the world's export of the in shell nuts. According to IBGE (2015), in 2014, Brazil produced 37,499 tons of the nut, Acre State being the largest producer amongst the Amazonian States, with a concentration of $36 \%$ of the total production (13,684 tons), followed by Amazonas State with 34\% (12,801 tons). A large part of this production is already being processed inside the State, which adds greater value to the product, and hence a greater income for the extractivists. Of the non-timber products exploited in the Amazon, the Brazil nut enjoys the major position, being responsible for the economic support of many extractivist families. Its exploitation became the main extractivist economic activity in this region after the decline of rubber extraction.

Improper management is likely to favour postharvest contamination, constituting a major problem for the marketing of the Brazil nut. This is evident from the fact that the maturing and dropping of the pods (Brazil nut fruit) coincide with the heavy rainfall season, thus delaying their collection. During the pod dropping season, it is dangerous to walk under the trees, this being another reason why the extractivists avoid collecting the fruits for several months. Since the fruits remain in contact with the soil for a prolonged period, this can be a natural cause of potentially aflatoxin-producing fungi (AFPA) and these compounds can contaminate the nuts. Aspergillus flavus and $A$. nomius are common aflatoxin producers on Brazil nuts (MIDORIKAWA et al., 2014; REIS et al., 2012; OLSEN et al., 2008), the aflatoxigenic species $A$. arachidicola, A. bombycis, $A$. parasiticus and $A$. pseudotamarii being less frequently isolated (REIS et al., 2012; BAQUIÃO et al., 2012; GONÇALVES et al., 2012). According to the International Agency of Research on Cancer (IARC, 2002), aflatoxins are considered to be carcinogenic.

Aflatoxigenic fungi were found throughout the whole Brazil nut production chain (CALDERARl et al., 2013). Concern with the contamination of Brazil nuts by aflatoxins started after notifications of the increased occurrence of aflatoxins in the nuts were reported in 2003 by the Rapid Alert System for Food and Feed (EC, 2003). This triggered a reduction of $99.3 \%$ to exports of the in-shell Brazil nuts from Brazil to the European Union countries between the years 2003 and 2005 (ALICE WEB, 2003) and the establishment of special conditions (EUROPEAN UNION, 2003) for the import of in-shell Brazil nuts by those countries from Brazil. Amongst these conditions, the Good Production Practices service can be highlighted.
In 2004, the Brazilian Food Safety Program - Field, a joint national action by the entities SENAI/SEBRAE/EMBRAPA (EMBRAPA, 2004), was structured as a from farm to fork program, aiming at producing a document that would instruct producers on how to better control and monitor the whole Brazil nut chain. The program integrates the activities of monitoring, control, inspection and tracking of contaminants, including mycotoxins. Although the Good Practices recommendations suggested by Codex Alimentarius (CAC, 2005) have improved product quality, natural drying can also be regarded as a step that promotes contamination, this being traditionally done by exposing the product to natural environmental conditions, thus a slow process which affords ample time for product contamination. The Project Safenut results (STDF, 2008) used for formulating recommendations to update the previous Codex Code of Practice for Aflatoxin in Tree nuts (CAC, 2010), showed that the Critical Control Point was the drying step in the community, and recommended that the drying in the communities be more efficient, with the use of simple drying equipment. Gonçalves et al. (2010) recommended a stationary forced convection drier using heated air for drying in-shell Brazil nuts. However, the use of the dryer requires electrical energy, which is not always available under the conditions found in extractivist forests.

Thus the objective of the present study was to evaluate the influence of a high-temperature drier using natural convection in the pre-drying step, on the quality of in-shell Brazil nuts.

\section{Material and methods}

Newly collected in-shell Brazil nuts were obtained from the Chico Mendes Extractive Reserve in the City of Brasiléia, Acre State, Brazil (1049'12"S and 6846'18"W Gr) between January and February 2011. The Brazil nuts were transported to the EMBRAPA Laboratory of Food Technology in the City of Rio Branco, Acre State. The experiment was carried out using a random block design with two treatments (before and after drying) and 10 replications, using $3 \mathrm{~kg}$ of in-shell Brazil nuts for each replication. The collection methodology was established according to the European Community Regulation n 401/2006 (EUROPEAN UNION, 2006), with the number of batches being defined and, according to their masses, the number of incremental samples to be collected from the same point of each batch. The samples were prepared for the determination of mycotoxins according to Normative Instruction $n^{\circ} 11$ of the Brazilian Ministry of Agriculture (BRASIL, 2010). The in-shell Brazil nuts were submitted to 6 hours of drying, where the nuts were arranged in $15 \mathrm{~cm}$ layers and stirred every 30 minutes. The overall dimensions of the drier (Figure 1) were $1.0 \mathrm{~m}$ wide $\times 2.0 \mathrm{~m}$ long $\times 1.70 \mathrm{~m}$ height, consisting of the furnace, heat exchanger, flue, plenum chamber and drying chamber (NOGUEIRA; ÁLVARES, 2012). The drier 

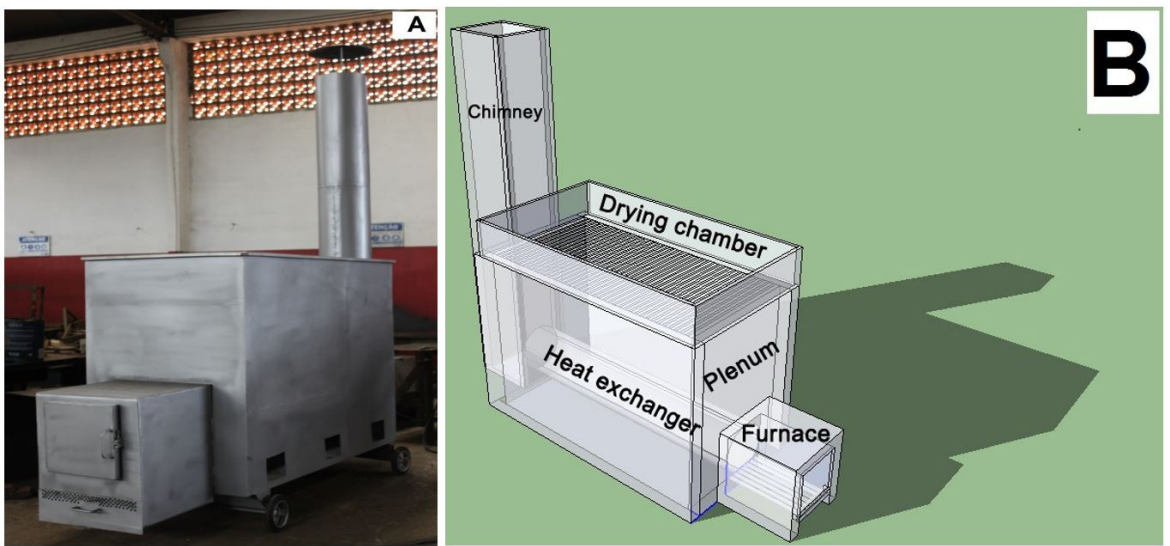

Figure 1. High-temperature natural convection dryer used during the experiment $(A)$ and its components (B).

was calibrated to handle an average of 200 to $300 \mathrm{~L} \mathrm{day}^{-1}$, powered by burning wood or Brazil nut pods, and manually controlling the drying air temperature at $45^{\circ} \mathrm{C}$.

Each repetition used a total of $3 \mathrm{~kg}$ of nuts. Before and after drying, duplicate samples were collected at random, without removing nuts considered bad (rotten, shrivelled and other defects), homogenized, peeled and crushed. After crushing, $500 \mathrm{~g}$ were removed for the analysis of aflatoxins and $100 \mathrm{~g}$ of for the microbiological analysis. Of the $100 \mathrm{~g}$ sample $40 \mathrm{~g}$ was used to quantify Aspergillus flavus and Aspergillus parasiticus and to make the total filamentous fungal count and $60 \mathrm{~g}$ was used for the physicochemical analysis. The samples were analysed for: moisture content in an oven with forced air circulation (Biopar, S180ST, Porto Alegre, Brazil) at $95^{\circ} \mathrm{C} / 5$ hours (method 925.40, AOAC, 2012); ash by incineration in a muffle furnace (Quimis, Q318M25T, Diadema, Brazil) at $525{ }^{\circ} \mathrm{C}$ (method 950.49, AOAC, 2012); ether extract by the Soxhlet method in an oil and grease extractor (Tecnal, TE044, Piracicaba, Brazil) (method 948.22, AOAC, 2012); total protein by the micro-Kjeldahl method in a nitrogen distiller, followed by multiplication of the result by 5,46 (Tecnal, TE036/2, Piracicaba, Brazil) (method 950.48, AOAC, 2012); crude fibre, by digestion in a fibre analyser (Marconi, MA444/CT, Piracicaba, Brazil) with 1.25\% w/V $\mathrm{H}_{2} \mathrm{SO}_{4}$ and $1.25 \% \mathrm{w} / \mathrm{V} \mathrm{NaOH}$ solutions (method 935.53, AOAC, 2012); carbohydrates by difference; water activity by direct reading on a portable water activity meter (Pawkit, Decagon, Toowoomba, Australia); and the total fungal and potentially aflatoxin-producing fungal counts by surface plating with dilution, as described by Pitt et al. (1983). Aflatoxins $B_{1}, B_{2}, G_{1}, G_{2}$ and total aflatoxins were quantified by solvent extraction followed by purification in immunoaffinity columns, and quantification by High Performance Liquid Chromatography (HPLC, Shimadzu) using post-column derivatization in a Kobra-cell ${ }^{\circledR}$ electrochemical cell according to method 994.08 (AOAC, 2012) and Stroka et al. (2000), using a fluorescence detector (HPLC/Kobra-cell/DFL). The aflatoxins were quantified by external standardization.
The method was previously in-house validated by Castro et al. (2013) and the detection limits were $0.04 ; 0.02 ; 0.03$ and 0.03 and quantification limits $0.13 ; 0.08 ; 0.10$ and 0.11 for aflatoxins B1, B2, G1 and G2, respectively. Column chromatography with a Shimpack CLC-ODS (M) 250 x $4.6 \mathrm{~mm}$ column was used, with a mobile phase of water: acetonitrile: methanol (6: 2: $2, \mathrm{v} / \mathrm{v} / \mathrm{v})$, flow rate of $1 \mathrm{~mL}$ $\min ^{-1}$, and injection volume of $50 \mu \mathrm{L}$.

The results were submitted to a verification of the presence of outliers, normality of errors and homogeneity of variances. Subsequently an analysis of variance of the original and/or transformed data was carried out and verified by the $\mathrm{F}$ test (5\%) for the existence of differences between the treatments. The Wilcoxon nonparametric test was applied to the variables that were not obtained by data transformation, in order to promote standardization of the errors and/or homogeneity of the variances. The t test was also applied (5\%) to compare the means of certain variables with the results obtained in other studies.

\section{Results and discussion}

Drying the in-shell Brazil nuts for 6 hours at $45^{\circ} \mathrm{C}$ significantly influenced the nut moisture content (Table 1), with an average reduction of $39.57 \%$ as compared with the baseline.

According to Álvares et al. (2009), by using the traditional technique of drying by natural aeration for 15 days in extractive communities in Acre State, Brazil, they can reach a $55.30 \%$ reduction in the nut moisture content. However, the same authors concluded that this drying time was too long. Thus the use of the dryer was effective in accelerate the velocity of moisture reduction ( 6 hours drying), reducing the drying time by $98.3 \%$ in relation to the traditional method used by the extractivists (15 days). Comparing the two systems, the dryer uses only $1.67 \%$ of the drying time (6 hours compared with 360 hours) to reach $71 \%$ of the moisture content reduction $(39.57 \%$ as compared to $55.30 \%$ ) obtained by the traditional method. 
This stage of the drying step can be considered as pre-drying in the extractivists communities, since the product will subsequently be properly dried during industrialization to approximately $4.0 \%$ of moisture. However, if the pre-drying is not done in the field, the product may lose quality during the long storage time, resulting in major problems such as fungal proliferation, including the production of aflatoxins. Calderari et al. (2013) added that in practice, rapid traditional drying as recommended by STDF (2008) is not always possible, because the collection of the Brazil nuts in the Amazon region depends on climatic and logistic conditions. However aflatoxigenic fungal growth and the production of aflatoxin increase rapidly between 40 and 90 days after collection of the nuts and their arrival at the processing plant for final drying (JOHNSSON et al., 2008). This recommendation only reinforces the need for the use of some equipment for artificial drying by the extractivists, to accelerate the pre-drying process.

Artificial drying of the in-shell Brazil nuts significantly affected the total filamentous fungal count, reducing it by $6.6 \%$ in comparison with the initial contamination (Table 1). According to Garcia et al. (2012), fungal growth depends on the interaction between the temperature and the moisture, which are the most important variables in their growth. The relationship between the moisture content of the nuts and fungal growth indicated that the reduction in moisture content was efficient in reducing pre-existing fungal contamination in the product (Table 1). However, the fungi already contaminate the nuts in the forest (STDF, 2008), since they are present in the soil (CALDERARI et al., 2013; BAQUIÃO et al., 2012) and in the air (BAQUIÃO et al, 2012) near the production area as well as in the Brazil nut pods in the forest (BAQUIÃO et al., 2012; ARRUS et al., 2005).
The longer the pods are in contact with the soil, the greater the predominance of $A$. flavus (BAQUIÃO et al., 2012) in this initial contamination. This variable is difficult to control since the extractivists traditionally harvest the nuts after the rainy season, even after receiving the recommendation (CAC, 2010; STDF 2008) to harvest the fruits immediately after they fall. It is likely that drying at higher temperatures will be more efficient in reducing the initial contamination of total fungi, because temperatures between 45 and $60^{\circ} \mathrm{C}$ are lethal to most phytopathogenic microorganisms, although in the case of in-shell Brazil nuts, temperatures above $50^{\circ} \mathrm{C}$ can damage the shell by cracking it (NOGUEIRA, 2011).

However, the water activity, potentially aflatoxin-producing fungi (AFPA) (Table 1) and the aflatoxin concentration in the in-shell Brazil nuts (Table 2) were not influenced by the drying process.

The water activity remained at a high value even after pre-drying, which was close to the optimum value for the growth of Aspergillus flavus (0.80-0.95) (PEREIRA et al., 2002), and aflatoxin production (0.68-0.87) (ARRUS et al., 2005).

Baquião et al. (2012) demonstrated that water activity plays an important role in fungal growth during this period, with a consequent potential risk for aflatoxin production. Calderari et al. (2013) observed that the water activities of Brazil nuts, both shelled and in-shell, were often very high (average of 0.95 and 0.94 ) in samples from the rainforest. Several factors influence fungal growth and aflatoxin production, but the length of time the Brazil nuts are stored in the optimal water activity range for aflatoxin production during primary and secondary warehouse storage in the forest, and in the processing plant before they reach the safe moisture level, is considered to be the most critical factor (VARGAS et al., 2011). The Codex code

Table 1. Means for the moisture content (MC), water activity (Aw), potentially aflatoxin-producing fungi (AFPA) and total filamentous fungi (FFT) found in Brazil nuts before and after high temperature drying by natural convection, Rio Branco City, Acre State, Brazil.

\begin{tabular}{|c|c|c|c|c|}
\hline Treatments & MC & Aw & $\begin{array}{c}\text { AFPA } \\
(\log \text { CFU g-1) }\end{array}$ & $\begin{array}{c}\text { FFT } \\
\left(\log \text { CFU g }{ }^{-1}\right)\end{array}$ \\
\hline Before drying & $26.91^{a}$ & $0.97^{a}$ & $4.06^{a}$ & $5.30^{a}$ \\
\hline After drying & $16.23^{b}$ & $0.99^{a}$ & $4.07^{a}$ & $4.95^{b}$ \\
\hline CV (\%) & 5.25 & $-^{*}$ & 5.89 & 3.82 \\
\hline
\end{tabular}

Means followed by the same letter in the samet column, show no differences by the t test at $5 \%$ of probability. Means of 10 repetitions in duplicate. *Wilcoxon nonparametric test. CV - coefficient of variation.

Table 2. Means for the aflatoxins (AFLA) found in Brazil nuts before and after high-temperature drying by natural convection, Rio Branco City, Acre State, Brazil.

\begin{tabular}{cccccc} 
Treatments & \multicolumn{5}{c}{ AFLA $\left(\boldsymbol{\mu g} \mathbf{~ k g}^{-1}\right)$} \\
\cline { 2 - 6 } & $\mathbf{B 1}$ & $\mathbf{B 2}$ & $\mathbf{G 1}$ & $\mathbf{G 2}$ & Total \\
Before drying & $2.952^{\mathrm{a}}$ & $0.326^{\mathrm{a}}$ & $4.742^{\mathrm{a}}$ & $0.009^{\mathrm{a}}$ & $8.228^{\mathrm{a}}$ \\
After drying & $0.803^{\mathrm{a}}$ & $0.137^{\mathrm{a}}$ & $0.070^{\mathrm{a}}$ & $0.081^{\mathrm{a}}$ & $1.116^{\mathrm{a}}$ \\
CV $(\%)$ & 148.32 & 126.01 & $-^{*}$ & $-^{*}$ & $-^{*}$ \\
\hline
\end{tabular}

Means followed by the same letter in the same column show no differences by the t test at $5 \%$ of probability. Means of 10 repetitions in duplicate. *Wilcoxon nonparametric test. CV - coefficient of variation. 
of practice recommends that nuts should be dried to a safe moisture level (water activity below 0.70) (CAC, 2010) within 10 days after collection from the forest, after the removal of damaged, rotten, empty and rancid nuts (STDF, 2008). However, although a low water activity is obtained just after processing (SANTOS et al., 2011) or after storage with in-shell Brazil nuts under forced ventilation (COSTA et al., 2016), this is not yet the case for the traditional pre-drying carried out in extractivist communities, which endorses the observation that Brazil nuts should preferably not be stored within the communities. Santos et al. (2011), for example, analysing processed Brazil nuts, packed in laminated flexible packs and in cardboard boxes, found low water activity (0.47) in the samples, which is an unfavourable condition for the growth of microorganisms. Costa et al. (2016) in studies with in-shell Brazil nuts stored in a forced aeration silo, found that the water activity observed was below 0.70 after nearly 90 days of storage.

Although there was a total reduction in fungi due to pre-drying, contamination by potentially aflatoxin-producing fungi (AFPA) in the nuts was not influenced (Table 1). It should be noted that while the dryer was effective in maintaining the pre-existing contamination by potential AFPA, further testing is required to arrive at the ideal drying time and rest period of the nuts to decrease their water activity. Calderari et al. (2013) found infections by fungi with the potential to produce aflatoxin in these samples as STDF (2008). Moreover, Leite et al. (2014) detected aflatoxin in Brazil nut samples without detecting any aflatoxigenic fungal growth. According to Pacheco (2007), intermediate fungi, including A. flavus and A. parasiticus, grow at water activities from 0.80 to 0.86 . However, in the present study, these fungi appeared at an average water activity value of 0.98 , as well as for Calderari et al. (2013) in rainforests. Whereas aflatoxins are thermostable (NUNES et al., 2003), it is possible that some of the potential AFPA detected were from non-aflatoxigenic strains, or that some field conditions may or may not have enabled the production of these toxins. According to Arrus et al. (2005) and Leite et al. (2014), although the fungi of the genus Aspergillus are toxin producers, they are not always related to the presence of aflatoxins. Nunes et al. (2003) added that the fungus can be inactivated or eliminated during processing, and may not be present in the manufactured product, although any mycotoxins produced will remain. According to Calderari et al. (2013), Brazil nuts contain a range of fungi, but the Aspergillus section Flavi are of major concern because some of them have the potential to produce aflatoxin. However, Olsen et al. (2008) asserted that Aspergillus nomius may be a common aflatoxin-producing species in Brazil nuts, possibly occurring in the samples analysed, but not detected by the AFPA-specific reagent.

The means aflatoxin concentrations found in the nuts analysed in this study (Table 2) were 1.877, 0.231,
2.406, 0.045 and $4.672 \mu \mathrm{g} \mathrm{kg}^{-1}$ for aflatoxin B1, aflatoxin B2, aflatoxin $\mathrm{G} 1$, aflatoxin $\mathrm{G} 2$ and total aflatoxin, respectively. Possibly due to the large variation in contamination between the samples, which is expected due to their microbiological nature and the sampling procedure, there was a high coefficient of variation for the variables aflatoxin B1 and aflatoxin B2, such that there was no significant difference between the same treatments, the values apparently decreasing after drying. The same occurred with the values for $\mathrm{G} 1$ and total aflatoxin, where there was high variability in the contamination between samples, as analysed by the Wilcoxon nonparametric test. Furthermore, aflatoxin was detected in only 40\% (B1), 40\% (B2), 30\% (G1), 15\% (G2), and $50 \%$ (total) of the samples with fungal growth, suggesting that when aflatoxigenic fungi are found, there may not be enough to produce aflatoxin, and also suggesting there are aflatoxigenic and non-aflatoxigenic strains. However, Pacheco et al. (2010) observed a strong association between the presence of aflatoxigenic fungi and aflatoxin production, and Vargas et al. (2011) demonstrated the risk from the aflatoxins associated with the shells of Brazil nuts, with higher correlations between the aflatoxin concentrations in in-shell Brazil nuts.

Furthermore, the aflatoxin concentrations were below the limits established by Brazilian legislation for total aflatoxin in shelled Brazil nuts, for both direct human consumption (10 $\mathrm{g} \mathrm{kg} \mathrm{kg}^{-1}$ ) and for processing $\left(15 \mu \mathrm{g} \mathrm{kg}^{-1}\right)$ (BRASIL, 2011). For in-shell Brazil nuts, the total aflatoxin concentrations were also lower than the limits established by Brazilian legislation $\left(20 \mu \mathrm{g} \mathrm{kg}^{-1}\right)$. Regarding the European Union, the limits set for contamination in in-shell Brazil nuts for processing are $8 \mu \mathrm{g} \mathrm{kg}^{-1}$ for aflatoxin B1 and $15 \mu \mathrm{g} \mathrm{kg}^{-1}$ for total aflatoxin; and for direct human consumption they are $5 \mu \mathrm{g} \mathrm{kg}^{-1}$ for aflatoxin B1 and $10 \mu \mathrm{g} \mathrm{kg}^{-1}$ for total aflatoxin (EUROPEAN UNION, 2010), hence the results were also lower.

With regards to contamination by aflatoxins, Xavier and Scussel (2008) found contamination levels ranging between $1.2 \mu \mathrm{g} \mathrm{kg}^{-1}$ and $11.5 \mu \mathrm{g} \mathrm{kg}^{-1}$ for total aflatoxin, which is higher than that observed in this study. Moreover, Leite et al. (2014) presented lower contamination levels for Brazil nuts collected at different times in Brasiléia City, Acre State, Brazil, of 0.073, 0.009, 0.034 and $0.007 \mu \mathrm{g} \mathrm{kg}^{-1}$ for aflatoxins B1, B2, G1 and G2, respectively. Pacheco and Scussel (2007) detected total aflatoxin levels from 1.2 to $11.5 \mu \mathrm{g} \mathrm{kg}^{-1}$ in in-shell Brazil nuts from the Amazon basin. Pacheco and Scussel (2009) reported that only $8.7 \%$ of the Brazil nuts contained aflatoxins at levels higher than European Union maximum level, $4 \mu \mathrm{g} \mathrm{kg}^{-1}$. Reis et al. (2012) found contamination by aflatoxin B1 above that mentioned in this work (11.9 to $1058.0 \mu \mathrm{g} \mathrm{kg}^{-1}$ for B1 aflatoxin), in samples from storage facilities in Acre State. Several factors are related to the differences in contamination found in the literature, the presence of the 
Table 3. Means for the ash (ASH), protein (PT), ether extract (EE), fibre (FB) and carbohydrate (CB) contents of Brazil nuts before and after high-temperature drying by natural convection in Rio Branco City, Acre State, Brazil, 2011.

\begin{tabular}{|c|c|c|c|c|c|}
\hline \multirow{2}{*}{ Treatments } & ASH & PT & EE & FB & CB \\
\hline & \multicolumn{5}{|c|}{$(\%)$} \\
\hline Before drying & $3.27^{b}$ & $14.87^{a}$ & $66.60^{a}$ & $7.99^{a}$ & $7.28^{a}$ \\
\hline After drying & $3.40^{a}$ & $15.14^{\mathrm{a}}$ & $63.17^{a}$ & $7.58^{a}$ & $9.96^{a}$ \\
\hline CV (\%) & 1.10 & 3.88 & 5.84 & 5.86 & 24.80 \\
\hline
\end{tabular}

Means followed by the same letter in the same column show no differences by the $\mathrm{F}$ test at $5 \%$ of probability. CV - coefficient of variation.

shell being one of these, and in-shell Brazil nuts showed higher contamination than shelled Brazil nuts (CAC, 2005). Not all isolates of $A$. flavus obtained from agricultural products have the capacity to synthesize aflatoxins (FREIRE; KOZAKIEWICZ, 2005). According to Pereira et al. (2002), confirmation of the presence of aflatoxigenic fungi in food is essential to apply control measures to reduce the aflatoxin-producing potential according to CAC (2010) and STDF (2008). Thus the control of the residence time of the pods (Brazil nut fruit) on the forest floor after dropping, along with the drying of the nuts, are measures aimed at reducing the incidence of aflatoxigenic fungi, and hence the production of aflatoxin.

In this study, contamination by aflatoxin G1 was greater than by aflatoxin B1, indicating, according to Olsen et al. (2008) who studied the relationship between aflatoxins B1 and $\mathrm{G} 1$ in samples of in-shell Brazil nuts, that the primary causes for the production of aflatoxin were not necessarily $A$. flavus and/or A. parasiticus, but also A. nomius which produces both aflatoxin types, $B$ and $G$. However, Soares et al. (2010) suggested that aflatoxin B1 occurred in greater amounts than aflatoxins B2, G1 and G2. These observations also agree with those of Silva et al. (2008), who concluded that the contamination by the fungus A. flavus prevailed over $A$. parasiticus, considering that $A$. flavus produces type $B$ aflatoxins and $A$. parasiticus produces type $G$ aflatoxins, also suggesting that the former is the main fungus responsible for contaminating the nuts. According to Garcia et al. (2012) and Baird et al. (2006), aflatoxin B1 is considered to be the most toxic and carcinogenic aflatoxin as compared with the other aflatoxins. Baquião et al. (2012) also found that a high percentage of aflatoxigenic $A$. flavus strains associated with high AFB1 production indicated the need for good management practices to prevent the occurrence of aflatoxins in Brazil nuts.

In relation to the composition of the nuts, with the exception of ash drying had no effect on the physicochemical characteristics of the nuts analysed (Table 3). The mean values were $3.33 \%$ ash, $15.00 \%$ protein, $64.89 \%$ ether extract, $7.79 \%$ fibre and $8.62 \%$ total carbohydrate. The values were lower $(p<0.05)$ than those obtained by Santos et al. (2011) for the protein (18.58\%), ether extract $(66.24 \%)$ and carbohydrate $(8.76 \%)$ contents of processed nuts from Pará State, Brazil, where the moisture content is lower (3.18\%). Comparing these results with those of Vasconcelos et al. (2011) for in natura nuts collected in the municipalities of Sena Madureira and Xapuri in Acre State, the values were higher for protein $(7.00 \%)$, ether extract (56.00\%) and fibre (6.00\%) and only lower for carbohydrate $(p<0.05)$, than the values obtained by Vasconcelos et al. (2011) (23.32\%). The small variation in the composition of the Brazil nuts in these studies probably originating from the different sampling sites.

Despite the reduction in the value obtained for ash, it was greater $(p<0.05)$ than that observed by Santos et al. (2011) of 3.32\%, and by Vasconcelos et al. (2011) of 3.00\%, and by Souza and Menezes (2008) of 3.00\%.

\section{Conclusions}

The natural convection dryer offers important advantages over the traditional drying procedure, reducing the moisture content of the nuts with a significant reduction in drying time, and with no change in the physicochemical composition of the nuts except for the ash content. Contamination by aflatoxin G1 was higher than by aflatoxin B1, indicating that the primary causes for the production of aflatoxin were not necessarily $A$. flavus and/or A. parasiticus, but also A. nomius, which produces both aflatoxin types, $B$ and $G$.

However, further studies are required on the influence of drying in-shell Brazil nuts in relation to aflatoxin contamination. The natural convection hot air dryer is an interesting option in relation to the traditional drying method, since it does not require electric energy and can use broken fruits, which are a residue of Brazil nut extraction in the Amazon, of excellent calorific potential.

\section{Acknowledgements}

The authors are grateful to the Coordination for the Improvement of Higher Level Personnel (CAPES) and to the National Council for Scientific and Technological Development (CNPq) in Brazil, for their financial support. 
Quality of in-shell Brazil nuts after drying using a pilot natural convection oven in the state of Acre, Brazil

Costa, D. A. et al.

\section{References}

ÁLVARES, V. S.; LEITE, F. M. N.; MADRUGA, A. L. S.; SOUZA, J. M. L.; COSTA, D. A. C. Monitoramento da cadeia produtiva da castanha-do-brasil quanto à contaminação por coliformes e fungos em três castanhais do Acre. In: SEMINÁRIO ANUAL DE COOPERAÇÃO UFAC-UF, 7., 2009, Rio Branco. Anais... Rio Branco: UFAC, 2009. p. 211-217. CD-ROM.

ARRUS, A. K.; BLANK, G.; ABRAMSON, D.; CLEAR, R.; HOLLEY, R. A. Aflatoxin production by Aspergillus flavus in Brazil nuts. Journal of Stored Products Research, v. 41, n. 5, p. 513-527, 2005. http://dx.doi.org/10.1016/j.jspr.2004.07.005.

ASSOCIATION OF OFFICIAL ANALYTICAL CHEMIST - AOAC. Official methods of analysis of the Association of Official Analytical Chemists. 19th ed. Gaithersburg: AOAC International, 2012.

BAIRD, R. E.; TRIGIANO, R. N.; WINDHAM, G.; WILLIAMS, P.; KELLEY, R.; ABBAS, H. K.; MOULTON, J. K.; SCRUGGS, M. $\mathrm{L}$. Comparison of aflatoxigenic and non aflatoxigenic isolates of Aspergillus flavus using DNA amplification fingerprinting techniques. Mycopathologia, v. 161, n. 2, p. 93-99, 2006. http:// dx.doi.org/10.1007/s11046-005-0121-3.

BAQUIÃO, A. C.; ZORZETE, P.; REIS, T. A.; ASSUNÇÃO, E.; VERGUEIRO, S.; CORREA, B. Mycoflora and mycotoxins in field samples of Brazil nuts. Food Control, v. 28, n. 2, p. 224-229, 2012. http://dx.doi.org/10.1016/j.foodcont.2012.05.004.

BRASIL. Ministério da Agricultura, Pecuária e Abastecimento. Instrução Normativa n 11, de 22 de março de 2010. Critérios e procedimentos para o controle higiênico-sanitário da castanhado-brasil e seus subprodutos, destinados ao consumo humano. Diário Oficial [da] República Federativa do Brasil, Brasília, DF, 2010.

BRASIL. Ministério da Saúde. Agência Nacional de Vigilância Sanitária. Resolução RDC nº 7, de 18 de fevereiro de 2011. Limites máximos tolerados (LTM) para micotoxinas em alimentos. Diário Oficial [da] República Federativa do Brasil, Brasília, DF, 2011.

CALDERARI, T. O.; IAMANAKA, B. T.; FRISVAD, J. C.; PITT, J. I.; SARTORI, D.; PEREIRA, J. L.; FUNGARO, M. H. P.; TANIWAKI, M. H. The biodiversity of Aspergillus section Flavi in brazil nuts: from rainforest to consumer. International Journal of Food Microbiology, v. 160, n. 3, p. 267-272, 2013. PMid:23290234. http://dx.doi.org/10.1016/j.ijfoodmicro.2012.10.018.

CASTRO, I. M.; ANJOS, M. R.; TEIXEIRA, A. S. Análise de aflatoxinas B1, G1, B2 e G2 em castanha-do-brasil, milho e amendoim utilizando derivatização pós-coluna no sistema cromatográfico CLAE/Kobra-Cell ${ }^{\otimes} / \mathrm{DFL}$. Rio de Janeiro: Embrapa Agroindústria de Alimentos, 2013. 6 p. (Comunicado Técnico, 198). Available at: <https://www.infoteca.cnptia.embrapa.br/ bitstream/doc/977550/1/2013CTE0198.pdf>. Accessed on: 4 Aug. 2016.
CODEX ALIMENTARIUS COMMISSION - CAC. Code of practice for the prevention and reduction of aflatoxin contamination in tree nuts. Rome: Joint FAO/WHO Food Standards Programme, 2005. 9 p. CAC/RCP-59-2005.

CODEX ALIMENTARIUS COMMISSION - CAC. Proposed draft revision of the additional measures for the prevention and reduction of aflatoxin contamination in Brazil nuts. Rome: Joint FAO/WHO Food Standards Programme, 2010. p. 58. Appendix 6. ALINORM 10/33/41.

COSTA, D. A.; ÁLVARES, V. S.; NOGUEIRA, R. M.; KUSDRA, J. F.; MACIEL, V. T.; MIQUELONI, D. P. Quality of Brazil nuts stored in forced aeration silos. Revista Ceres, v. 63, n. 3, p. 305-314, 2016. http://dx.doi.org/10.1590/0034-737X201663030005.

EMPRESA BRASILEIRA DE PESQUISA AGROPECUÁRIA EMBRAPA. Manual de segurança e qualidade para a cultura da castanha-do-brasil. Brasília: Embrapa Informação Tecnológica, 2004. 62 p. (Projeto PAS Campo; Série Qualidade e Segurança dos Alimentos).

EUROPEAN COMMISSIONS - EC. Rapid Alert System for Food and Feed (RASFF). Annual Report on the functioning of the Rasff. Brussels, 2003. Available at: <http://ec.europa.eu/food/ safety/rasff/docs/rasff_annual_report_2003_en.pdf>. Accessed on: 3 Aug. 2016.

EUROPEAN UNION. European Union Commission (EC) $n^{\circ}$ 493/2003/EC of October 2003. Imposing special conditions on the import of Brazil nuts in shell originating in or consigned from Brazil. Official Journal of the European Union, Europa, L. 168, n. 46, p. 33-38, Oct. 2003.

EUROPEAN UNION. Commission Regulation (EC) n 401/2006 of 23 February 2006. Laying down the methods of sampling and analysis for the official control of the levels of mycotoxins in foodstuffs. Official Journal of the European Union, Europa, L. 57, n. 70, p. 12-34, Apr 2006.

EUROPEAN UNION. Commission Regulation (EC) n 165/10 of 26 February 2010. Amending Regulation (EC) no 1881/06 setting maximum levels for certain contaminants in foodstuffs as regards aflatoxins. Official Journal of the European Communities, United Kingdom, L. 50, p. 8-12, 2010.

FREIRE, F. C. O.; KOZAKIEWICZ, Z. Filamentous fungi, bacteria and yeasts associated with cashew kernels in Brazil. Revista Ciência Agronômica, v. 36, n. 2, p. 249-254, 2005.

GARCIA, D.; RAMOS, A. J.; SANCHIS, V.; MARÍN, S. Effect of Equisetum arvense and Stevia rebaudiana extracts on growth and mycotoxin production by Aspergillus flavus and Fusarium verticillioides in maize seeds as affected by water activity. International Journal of Food Microbiology, v. 153, n. 1-2, p. 21-27, 2012. PMid:22104120. http://dx.doi.org/10.1016/j. ijfoodmicro.2011.10.010.

GONÇALVES, J. S.; FERRACIN, L. M.; VIEIRA, M. L. C.; IAMANAKA, B. T.; TANIWAKI, M. H.; FUNGARO, M. H. P. Molecular analysis 
Quality of in-shell Brazil nuts after drying using a pilot natural convection oven in the state of Acre, Brazil Costa, D. A. et al.

of Aspergillus section Flavi isolated from Brazil nuts. World Journal of Microbiology \& Biotechnology, v. 28, n. 4, p. 1817-1825, 2012. PMid:22805966. http://dx.doi.org/10.1007/ s11274-011-0956-3.

GONÇALVES, R. C.; Álvares, V. S.; CARTAXO, C. B. C.; WADT, L. H. O.; SOUSA, J. M. L.; LIMA, A. C.; COSTA, D. A.; GIACOMELLI, M.; MAGALHÃES, K. S.; MADRUGA, A. L. S. Secador estacionário a ar aquecido forçado artificialmente: inovação tecnológica na secagem de sementes de castanheirada-amazônia (Bertholletia excelsa). Rio Branco: Embrapa Acre, 2010. 4 p. (Comunicado Técnico, 174).

INSTITUTO BRASILEIRO DE GEOGRAFIA E ESTATÍSTICA IBGE. Produção da extração vegetal e da silvicultura. Rio de Janeiro, 2015. Available at: <http://www.ibge.gov.br/home/ estatistica/economia/pevs/2013/default_pdf.shtm>. Acessed on: 20 May 2015.

INTERNATIONAL AGENCY FOR RESEARCH ON CANCER IARC. Some traditional herbal medicines, some mycotoxins, naphthalene and styrene. Lyon: WHO, 2002. (IARC Monographs on the Evaluation of Carcinogenic Risks to Humans, 82).

JOHNSSON, P.; LINDBLAND, M.; THIM, A. M.; JONSSON, N.; VARGAS, E. A.; MEDEIROS, N.; BRABET, C.; QUARESMA DE ARAÚJO, M.; OLSEN, M. Growth of aflatoxigenic moulds and aflatoxin formation in Brazil nuts. World Mycotoxin Journal, v. 1, n. 2, p. 127-137, 2008. http://dx.doi.org/10.3920/WMJ2008.1033.

LEITE, F. M. N.; SOUZA, M. L.; SOUZA, J. M. L.; CARTAXO, C. B. C.; ÁLVARES, V. S.; CUNHA, C. R. Incidence of Aspergillus flavus, Aspergillus parasiticus and aflatoxins in Brazil nut in the Amazon forest environment. World Mycotoxin Journal, v. 7, n. 2, p. 199-205, 2014. http://dx.doi.org/10.3920/WMJ2012.1488.

MIDORIKAWA, G. E. O.; SOUSA, M. L. M.; SILVA, O. F.; DIAS, J. S. A.; KANZAKI, L. I. B.; HANADA, R. E.; MESQUITA, R. M. L. C.; GONÇALVES, R. C.; ALVARES, V. S.; BITTENCOURT, D. M. C.; MILLER, R. N. G. Characterization of Aspergillus species on Brazil nut from the Brazilian Amazonian region and development of a PCR assay for identification at the genus level. BMC Microbiology, v. 14, p. 138, 2014. http://dx.doi.org/10.1186/1471-2180-14-138.

NOGUEIRA, R. M. Secagem da castanha-do-brasil em condições de floresta e carbonização do resíduo do fruto da castanheira. 2011. 150 f. Tese (Doutorado em Engenharia Agrícola)-Engenharia de Processamento de Produtos Agrícolas, Universidade Federal de Viçosa, Viçosa, 2011.

NOGUEIRA, R. M.; ÁLVARES, V. S. Secador à alta temperatura por convecção natural: solução para a pré-secagem da castanha-do-brasil no campo. Acre: Embrapa Acre, 2012. 6 p. (Comunicado técnico, 182). Available at: https://www.infoteca. cnptia.embrapa.br/bitstream/doc/995172/1/cot182.pdf>. Acessed: 04 Aug. 2016.

NUNES, I. L.; MAGAGNIN, G.; BERTOLIN, T. E.; FURLONG, E. B. Arroz comercializado na região Sul do Brasil: aspectos micotoxicológicos e microscópicos. Ciência e Tecnologia de
Alimentos, v. 23, n. 2, p. 190-194, 2003. http://dx.doi.org/10.1590/ S0101-20612003000200015.

OLSEN, M.; JOHNSSON, P.; MOLLER, T.; PALADINO, R.; LINDBLAD, M. Aspergillus nomius, an important producer in Brazil nuts. World Mycotoxin Journal, v. 1, n. 2, p. 123-126, 2008. http://dx.doi.org/10.3920/WMJ2008.1032.

PACHECO, A. M. Selênio e aflatoxinas em castanha-dobrasil (Bertholletia excelsa H.B.K.) e qualidade de produtos derivados. 2007. 144 f. Tese (Doutorado em Ciência de Alimentos)Universidade Federal de Santa Catarina, Florianópolis, 2007.

PACHECO, A. M.; LUCAS, A.; PARENTE, R.; PACHECO, N. Association between aflatoxin and aflatoxigenic fungi in Brasil nut (Bertholletia xcels H. B. K.). Ciência e Tecnologia de Alimentos, v. 30, n. 2, p. 330-334, 2010. http://dx.doi.org/10.1590/S010120612010000200007.

PACHECO, A. M.; SCUSSEL, V. M. Aflatoxins evaluation on in-shell and shelled dry Brazil nuts for export analysed by LC e MS/MS - 2006 and 2007 harvests. World Mycotoxin Journal, v. 2, n. 3, p. 295-304, 2009. http://dx.doi.org/10.3920/WMJ2008.1077.

PACHECO, A. M.; SCUSSEL, V. M. Selenium and aflatoxin level in raw Brazil nuts from Amazon basin. Journal of Agricultural and Food Chemistry, v. 55, n. 26, p. 11087-11092, 2007. PMid:18052094. http://dx.doi.org/10.1021/jf072434k.

PEREIRA, M. M. G.; CARVALHO, E. P.; PRADO, G. Crescimento e produção de aflatoxinas por Aspergillus flavus e Aspergillus parasiticus. Boletim do Centro de Pesquisa de Processamento de Alimentos, v. 20, n. 1, p. 141-156, 2002. http://dx.doi. org/10.5380/cep.v20i1.1143.

PITT, J. I.; HOCKING, A. D.; GLENND, R. An improved medium for the detection of Aspergillus flavus and A. parasiticus. The Journal of Applied Bacteriology, v. 54, n. 1, p. 109-114, 1983. PMid:6406419. http://dx.doi.org/10.1111/j.1365-2672.1983. tb01307.x.

REIS, T. A.; OLIVEIRA, T. D.; BAQUIÃO, A. C.; GONÇALVES, S. S.; ZORZETE, P.; CORREAA, B. Mycobiota and mycotoxins in Brazil nut samples from different states of the Brazilian Amazon region. International Journal of Food Microbiology, v. 159, n. 2, p. 61-68, 2012. PMid:23072689. http://dx.doi.org/10.1016/j. ijfoodmicro.2012.08.005.

SANTOS, O. V.; CORRÊA, N. C. F.; LANNES, S. C. S. Caracterização física, físico-química, microbiológica e micotoxicológica da castanha-do-brasil (Bertholletia excelsa H.B.K.). Revista Iluminart, v. 12, n. 7, p. 48-59, 2011.

SILVA, J. O.; CÂNDIDO, L. M. B.; NOVELLO, D.; MACHADO, C. Ocorrência de aflatoxinas em arroz consumido por militares do exército brasileiro por cromatografia em camada delgada e cromatografia líquida de alta eficiência. Ciência e Tecnologia de Alimentos, v. 32, n. 4, p. 1238-1244, 2008. http://dx.doi. org/10.1590/S1413-70542008000400031. 
SISTEMA DE ANÁLISE DAS INFORMAÇÕES DE COMÉRCIO EXTERIOR. Aliceweb. Brasília: MDIC, 2003. Available at: <http:// aliceweb.desenvolvimento.gov.br/>. Acessed: 11 Aug. 2016.

SOARES, C.; RODRIGUES, P.; FREITAS-SILVA, O.; ABRUNHOSA, L.; VENÂNCIO, A. HPLC method for simultaneous detection of aflatoxins and cyclopiazonic acid. World Mycotoxin Journal, v. 3, n. 3, p. 225-231, 2010. http://dx.doi.org/10.3920/WMJ2010.1216.

SOUZA, M. L.; MENEZES, H. C. Extrusão de misturas de castanha do Brasil com mandioca. Ciência e Tecnologia de Alimentos, v. 28, n. 2, p. 451-462, 2008. http://dx.doi.org/10.1590/S010120612008000200029.

STANDARDS AND TRADE DEVELOPMENT FACILITY - STDF. STDF 114: Project SafeNut - Final report covering period from 1 June 2006 to 30 November 2008 - Project: 'Validation and transfer to the key stakeholders of a sustainable and effective aflatoxin management system in the Brazil nut production chain for recovering and consolidating export markets. particularly in Europe'. Sweden: Scientific Coordinator Last version, 2008. Project co-ordinators: Catherine Brabet, General Co-ordinator and Monica Olsen, Scientific Co-ordinator.

STROKA, J.; ANKLAM, E.; JORISSEN, U.; GILBERT, J. Immunoaffinity column cleanup with liquid chromatography using post-column bromination for determination of aflatoxins in peanut butter, pistachio paste, fig paste and paprika powder: collaborative study. Journal of AOAC International, v. 83, n. 2, p. 320-340, 2000. PMid: 10772170.

VARGAS, E. A.; SANTOS, E. A.; WHITAKER, T. B.; SLATE, A. B. Determination of aflatoxin risk components for in-shell Brazil nuts. Food Additives and Contaminants, v. 28, n. 9, p. 12421260, 2011. PMid:21838597. http://dx.doi.org/10.1080/194400 49.2011 .596488 .

VASCONCELOS, A. A.; CRUZ, K.; WADT, L. O.; ABREU, L. F. Caracterização físico-química de amêndoas e óleos de castanhado-brasil (Bertholletia excelsa H.B.K.) provenientes do estado do Acre. In: SEMINÁRIO DE INICIAÇÃO CIENTÍFICA DA EMBRAPA AMAZÔNIA ORIENTAL, 15., 2011, Belém. Anais... Belém: Embrapa Amazônia Oriental, 2011. p. 1-4. Available at: <http:// www.alice.cnptia.embrapa.br/alice/bitstream/doc/899855/1/ RESUMOArthurFinalCorrigido.pdf>. Accessed on: 10 Sept 2015.

XAVIER, J. J. M.; SCUSSEL, V. M. Development of an LC-MS/ MS method for the determination of aflatoxins B1, B2, G1, and G2 in Brazil nut. International Journal of Environmental Analytical Chemistry, v. 88, n. 6, p. 425-433, 2008. http://dx. doi. org/10.1080/03067310701836816. 